\title{
The forgotten resource: Community perspectives on conservation and well-being in Zahamena National Park, Madagascar
}

\author{
Cara M. Raboanarielina
}

\author{
Africa Rice Center (AfricaRice) \\ Benin \\ E-mail: c.raboanarielina@cgiar.org
}

\begin{abstract}
This research examines local perceptions of social well-being in two forest-dependent communities near Zahamena National Park (ZNP), Madagascar. Key informant interviews were conducted to observe how local context, including community and ecological factors, influenced perceptions of social well-being. Overall, residents expressed a broad sense of decreased wellbeing as local forest resource access changed following the creation of ZNP. While one community was more dependent on forest and non-timber forest products for their livelihood, both communities believed lack of access to the park and its resources negatively affected local social well-being. Further, both communities felt ZNP provided few benefits to local residents. In addition, informants alluded to a sense of distrust of conservation managers and believed their needs and concerns were neither heard nor addressed by current conservation programs. Such data confirm people living in rural communities adjacent to protected areas have limited impact on conservation policies and initiatives on the island. Implications of this research suggest a reassessment of institutional conservation policy and practices to reflect locally held social traditions and community beliefs about conservation.
\end{abstract}

\section{RÉSUMÉ}

Cette étude examine les perceptions locales de la qualité de vie dans deux communautés dépendantes de la forêt et vivant à proximité du Parc National de Zahamena à Madagascar. Des entretiens ont été menés pour analyser comment le contexte local, tant au niveau des facteurs communautaires qu'écologiques, a influencé les perceptions portant sur la qualité de vie. En général, les résidents ont constaté une baisse de leur qualité de vie depuis la création du Parc à cause du changement draccès aux ressources forestières locales. Une des communautés dépendait des produits forestiers ligneux et non ligneux pour sa subsistance et une autre communauté a estimé que le fait de ne pouvoir accéder au Parc et à ses ressources avait détérioré son niveau de vie. En outre, les deux communautés ont considéré que le Parc avait fourni peu d'avantages aux résidents. Les personnes interviewées ont également exprimé une certaine méfiance à l'égard des gestionnaires du programme de conservation qui, selon elles, n'ont répondu ni à leurs besoins ni à leurs préoccupations. Ces résultats confirment que les communautés rurales vivant à proximité des aires protégées ont une influence limitée sur la politique et les initiatives de conservation à Madagascar. Cette recherche suggère que la politique de conservation doit être réévaluée et qu'il y a lieu de rechercher de nouvelles pratiques permettant d'intégrer les traditions sociales locales et les croyances communautaires dans les actions de conservation.

\section{INTRODUCTION}

Madagascar is widely known for its unique environment and biodiversity. Environmental conservation through the establishment of protected areas has been the primary method to preserve the country's forests and exceptional biodiversity (Andriamampianina 1984, Kull 1996). Protecting Madagascar's environment has significant global ecological importance as more than eighty percent of the flora and fauna found there are endemic (Battistini and Richard-Vindard 1972, Guillaumet 1984). Conservation initiatives through the establishment of protected areas have the potential to significantly impact local Malagasy citizens. In Madagascar, forest-dependent communities' livelihoods are negatively affected as access to forests and natural resources become increasingly prohibited due to the creation of protected areas (Shyamsundar and Kramer 1997, Marcus 2001, Ferraro 2002, Harper 2002). Communities within and adjacent to Zahamena National Park (ZNP) in eastern Madagascar are especially vulnerable; they lost access to forest resources and land when ZNP was declared a protected area.

The history of ZNP is one of contestation over park boundaries and resource access and use between the government and local communities (Rabesahala et al. 1994). ZNP was first established as a strict nature reserve (Réserve Naturelle Intégrale - RNI) on 31 December 1927 by (French colonial) government decree (Andriamampianina 1984). In June 1966, governmental Decree Number 66-242 amended the boundaries of ZNP to conform to the system of conservation governance adopted by the new administration of recently independent Madagascar (Madagascar National Parks 2009). Over thirty years later in August 1997, the boundaries of ZNP were modified once more; the Decree Number 97-1044 officially designated the national park (Conservation International 1999). In 2001, ZNP achieved national park status (PNM and Cl 2001). This status change made certain areas of the park accessible to tourists and researchers, but not to local communities living adjacent to ZNP. 


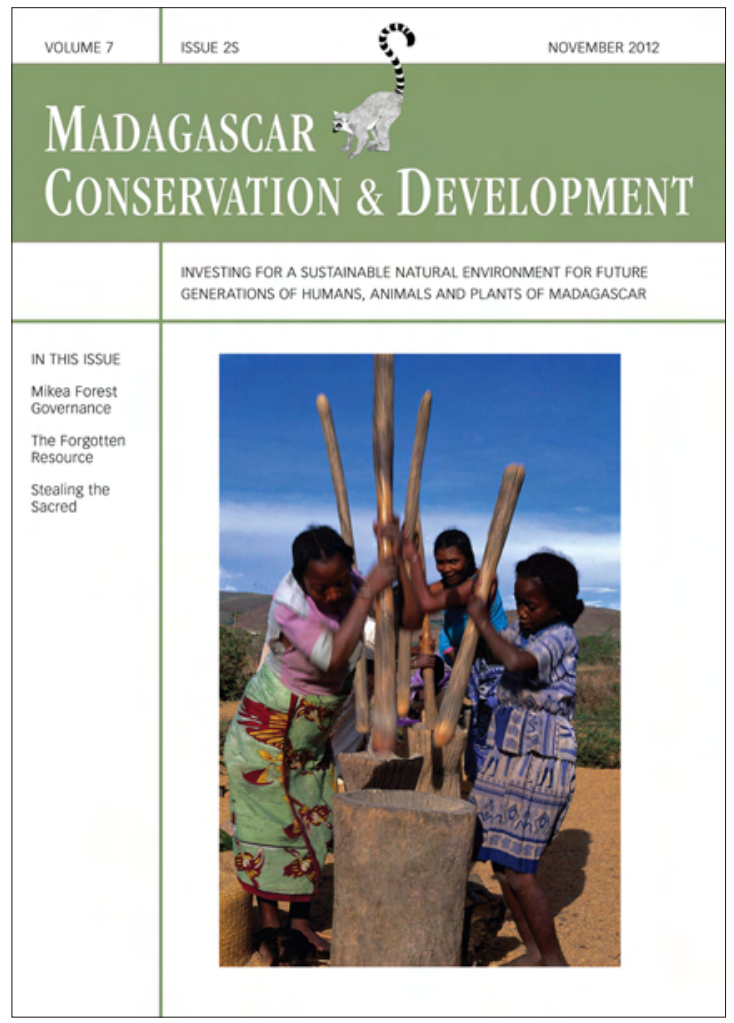

Madagascar Conservation \& Development is the journal of Indian Ocean e-Ink. It is produced under the responsibility of this institution. The views expressed in contributions to MCD are solely those of the authors and not those of the journal editors or the publisher.

All the Issues and articles are freely available at http://www.journalmcd.com

Contact Journal MCD

info@journalmcd.net for general inquiries regarding MCD funding@journalmcd.net to support the journal

Madagascar Conservation \& Development Institute and Museum of Anthropology University of Zurich

Winterthurerstrasse 190

$\mathrm{CH}-8057$ Zurich, Switzerland

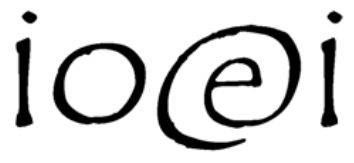

Indian Ocean e-Ink

Promoting African Publishing and Education www.ioeink.com

Missouri Botanical Garden (MBG)

Madagascar Research and Conservation Program BP 3391

Antananarivo, 101, Madagascar 
This research examines how restricted access at the local level affects the social well-being of forest-dependent communities in ZNP in Madagascar. Drawing on key informant interviews conducted in two communities in ZNP, this article explores the processes and factors related to the establishment of protected areas that impact well-being. This study examines how people's perceptions of social well-being are based on social as well as ecological and community factors. In contrast to prior literature that focused broadly on social impacts of conservation policy and practices related to community livelihoods and well-being, this study applies an integrated approach to evaluate ZNP residents' well-being perceptions. This conceptual approach emphasizes the interconnectedness of ecological, social, cultural, and political processes in place that shape social well-being. As a result, this article contributes to a growing literature that calls for the realignment of institutional conservation discourse to reflect community-identified perceptions of well-being and concerns about conservation (Ghimire and Pimbert 1997, Zerner 2000, Brechin et al. 2003).

\section{CONCEPTUAL BACKGROUND}

The research on the social impacts of conservation in Madagascar broadly addresses how protected areas influence local culture, livelihoods, public health, and create conflicts resulting from lost access to natural resources (Gezon 1997, Hanson 1997, Shyamsundar and Kramer 1997, Peters 1999, Ferraro 2002, Harper 2002, Sodikoff 2007, Keller 2008). Although these approaches examine aspects of well-being, they fail to explicitly define or evaluate the concept. Much of this problem is due to the ambiguity in defining well-being in the literature on the social impacts of conservation (D. Brockington, pers. comm., 1 February 2011). While understanding the specific outcomes related to livelihoods and well-being is important, this analysis offers an integrated approach to understand social well-being from a community perspective.

The community concept is significant for studies of social well-being because it is where the individual and society interests converge (Wilkinson 1991). Social well-being entails evaluations of one's own life situation as well as an assessment of wellness among others in the community. How individuals perceive or interpret a situation is deemed an expression of reality. "What is perceived as real is real in its consequences" (Thomas and Thomas 1928: 572). Based on the fundamentals of sociological theory, people's perceptions are considered accurate representations of their situations and/or experiences. Fundamentally, social well-being refers to the subjective evaluation of life satisfaction and the appraisal of one's circumstance and functioning in society; this is developed through individual social interaction (Wilkinson 1979, Keyes 1998, Deiner et al. 1999). This means individual well-being is required for social well-being in any given community setting (Wilkinson 1991). Values for others and felt needs are of secondary importance to first order needs such as sustenance. Maslow ((1954) in Wilkinson 1979) argued the human potential for social well-being only occurs when motives for survival, security, and esteem are satisfied. Sustenance is the first requirement of social well-being; it describes the act of meeting primary needs and freeing human energy from tensionreduction motives (Wilkinson 1979). Once sustenance needs are met, human energy and attention can be liberated for other uses and movement towards well-being. How much is required for an individual to move toward well-being is partly affected by how access to resources for meeting primary needs is distributed within a population, a third dimension of social well-being which Wilkinson (1991) termed ecological well-being. To the extent that ecological well-being refers "explicitly to natural and other conditions that support and sustain human life" (Wilkinson 1991: 68), an interactional approach to evaluating social well-being is critical, as it takes into consideration not only individual, but community and ecological well-being.

Building on the interconnections of the social and ecological, political ecology enables an examination of how specific politics and power relations in place affect access to natural resources (Watts 2000). Robbins's (2004: 149) 'conservation and control thesis' examines how access and control of natural resources is taken from local producers or groups through conservation efforts. Overall, his approach examines how various extra-local (either state or non-governmental organization) interests and efforts in the name of preserving biodiversity disrupt local social, cultural, and livelihood systems. To incorporate the contestation over resource access and use, the conceptual framework of well-being is merged with political ecology to understand the various ecological, social, cultural, and political processes in space to evaluate social well-being. Such an integrated approach contributes to the social impacts of conservation literature by underscoring how power relations within a locality affect social well-being (Gezon 1997, 2006, Simsik 2002).

\section{SETTING}

The study took place in two communities adjacent to Zahamena National Park Madagascar. Zahamena is located in the Alaotra-Mangoro and Analanjirofo regions (Figure 1). Reflecting the uniqueness of Madagascar's natural environment, ZNP has high rates of biodiversity where over 8,000 species of plants and animals are found within its 42,300 hectares (Mittermeier et al. 2005). ZNP is very isolated and lacks any road infrastructure. With the park's establishment as a strict nature reserve in 1927 by governmental decree, no human occupancy was allowed within its boundaries and scientific research was limited to select zones (Andriamampianina 1984). Under colonial rule, notably the 1947 rebellion against French colonial power, the forest became a haven for villagers eager to evade taxes and other forms of state repression (Rabesahala et al. 1994). Political instability encouraged a form of land grab and human occupation throughout the park by people fleeing the conflict occurring in the urban areas of the region. However, human settlement of ZNP began much earlier during the late 1800s (Rabesahala et al. 1994).

As of 2008, a total population of about 36,000 live in eight rural communes (komoina), thirty - two municipalities (fokontany), and 117 villages within ZNP and its periphery; the population density was about 33 people per square kilometer (MNP 2009). Residents of these communities are of the Sihanaka and Betsimisaraka tribes. The Sihanaka are predominantly located in the western region closest to Lac Alaotra (Alaotra-Mangoro region) while the Betsimisaraka are found in the central and eastern areas of the park within the Analanjirofo region. Antanandava and Ambodivoahangy were selected as the primary study sites because they each represent the dominant tribes of the area and have important geographical and institutional relationships 


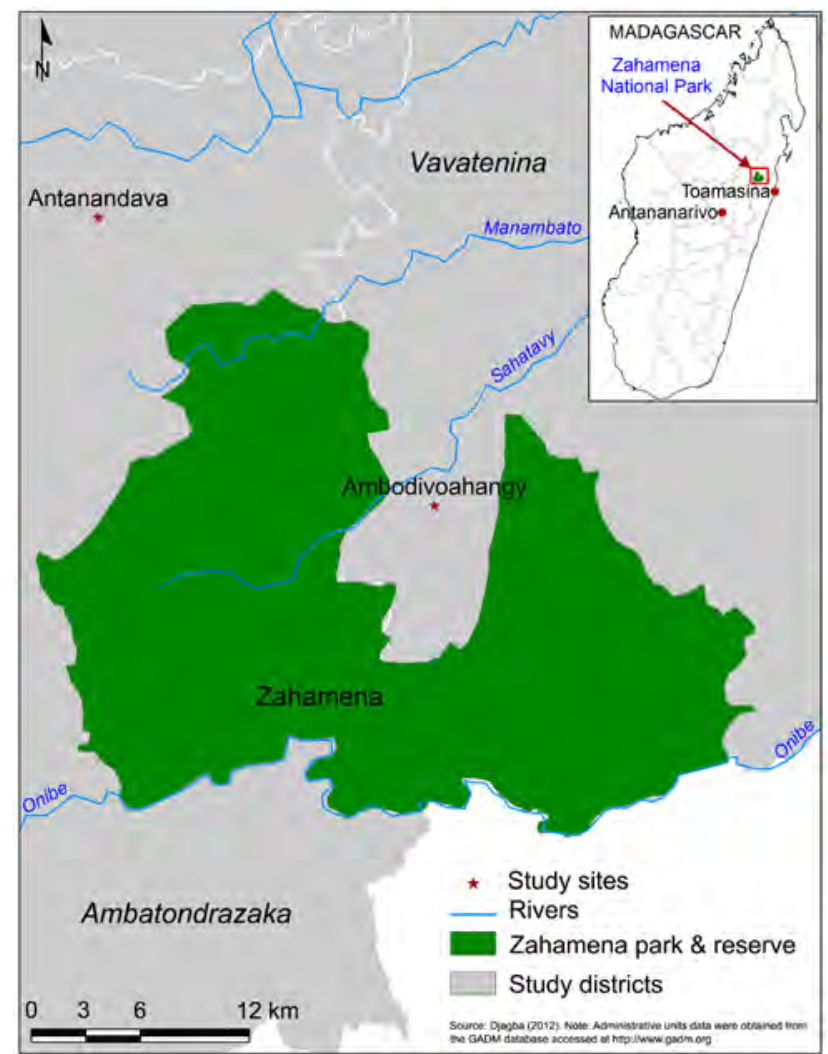

FIGURE 1. Study sites around Zahamena Protected Area

with ZNP (see Figure 1). Antanandava has unofficially served as the park entrance since it achieved national park status. Both communities have been recipients of several integrated conservation and development projects (ICDPS) implemented in the 1990s and 2000s. Also, the unique geographic location of Ambodivoahangy and its isolation within the enclave of the park were significant selecting factors. People there have used the park as a throughway for many years as they buy and sell goods in both the western and eastern regions of the park periphery.

The area is typical of much of Madagascar: rural communities dependent on subsistence agriculture and forest resources. Much of the population relies on subsistence farming, mainly rice as well as other crops, and forest resources for their livelihood. Antanandava is a larger town (komoina) and is more accessible to markets and road networks than Ambodivoahangy. Residents in Ambodivoahangy are very isolated; people must trek between 76 to 80 kilometers over hilly and steep terrain typical of the area to access any roads or formal markets. The only social infrastructure in Ambodivoahangy includes one elementary school and three churches. Social infrastructure as described here refers to the social institutions, including local government, social service institutions, and voluntary and civic organizations that exist within a locality (Swanson 1992).

\section{METHODOLOGY}

This research is part of a larger mixed-methods study combing multiple qualitative (key informant interviews, facilitated discussion groups, and participatory photography) and quantitative methods (household survey) to evaluate how changes in ZNP access impacted residents' social well-being. For the research reported here, forty-two key informant interviews were conducted with local ZNP residents, current and former park staff, and key government and non-government stakeholders (at local, regional, and national levels) involved in park management (see Table 1). In total, thirty-three ZNP residents (or community informants), five regional informants, and four national informants were interviewed from October to December 2009.

Interviewing enables researchers to observe aspects of social life and learn about specific social phenomena from participants' own words (Dutcher et al. 2004). Key informants are individuals with broad knowledge of their community, its history, and are recognized leaders in their community (Burdge 2004). Key informant interviews differ slightly from in-depth interviews as they provide an examination of social life in its context as opposed to individuals who have knowledge about a particular issue. The use of this methodology provided important individual- and community-level perspectives into the associated biophysical, social, and political processes related to social well-being. Because key informant interviews are conducted in context, so as to study phenomena in their natural setting, interpretations are rooted in participants' interpretations and observations, not derived from the researcher's perspective (Creswell 2007). Participants' views and perceptions are perceived as real (Thomas and Thomas 1928). By asking informants to report on their perceptions through interview questions enables the development of concepts from the participant's viewpoint and not that of the researcher (Creswell 2007). Due to informants' key position and familiarity with their community, they are more aware of local history, current issues, concerns, and power relations (Scott 1990) than other residents. Moreover, key informant interviews are an appropriate methodology when comparisons are made between communities as informants share similar positions within their respective communities.

Community informants included residents in elected and traditional leadership roles as well as local citizens and those with knowledge about ZNP, local conservation initiatives, and park management (see Table 1). Of these informants, sixteen were from Antanandava and seventeen were from Ambodivoahangy; all informants except one (park staff working in Ambodivoahangy) were residents of their respective community and not from surrounding villages. This included elected leaders (e.g., maire, sefo ny fokontany), traditional leaders (tangalamena), elders (ray aman'dreny), school administrators, religious leaders, representatives from various community associations, and representatives involved in park and conservation management at local, regional, and national levels. An initial list of informants identified by community occupation and position was compiled prior to data collection. Upon arrival in each study site, and reflective of Malagasy fomba (cultural norms), the research team requested a formal introduction with community representatives, e.g., the tangalamena (traditional leader) and/or sefo ny fokontany (elected leader). The purpose of these introductions was to gain permission to conduct the research and to obtain entrée into the community. Contact information for the initial list of community informants were obtained during these formal introductions with community leaders and individuals were recruited based on their knowledge and/or experience about conservation, their community, and ZNP. Using a snowball sampling procedure during the interviews, additional informants were selected by asking initial informants to identify other potential participants. By definition, key informant interviews are not meant to be representative of the population as it is not 
a sample. However, extensive efforts were made to purposively sample to include viewpoints of underrepresented groups and minorities within the community through snowball sampling. Access to potential informants was granted through personal referrals from previous informants. Recruitment of additional informants ceased when potential contacts and information became redundant and it was believed a fairly comprehensive account of opinions and insights had been attained (Weiss 1994). Recognizing the patriarchal structure of community leadership, which is typical of most rural Malagasy communities, the research team attempted to recruit and include additional female informants for a more gender-balanced perspective.

The interview guide consisted of 14 open-ended questions (see Supplementary Material). Informants were encouraged to elaborate on new themes that emerged during the interview discussion. These topics included local history, accounts of the establishment of ZNP, land shortage, and the local ramifications of the political crisis. All interviews were conducted in the local Malagasy dialect. Each interview was digitally recorded upon receiving permission from the participant and accompanied by detailed field notes. Prior to coding and analysis, interviews were transcribed and translated into English. While translations were conducted by native Malagasy speakers fluent in English and attempted to record verbatim informants' responses, interpre-

TABLE 1. Key informants by occupation and locality ( $N=42)$

\begin{tabular}{|c|c|}
\hline Informant type & $\begin{array}{l}\text { Number of } \\
\text { informants }\end{array}$ \\
\hline \multicolumn{2}{|l|}{ Community (ZNP Residents) ${ }^{a}$} \\
\hline Elected leader ${ }^{b}$ & 3 \\
\hline Traditional leader (Tangalamena) & 3 \\
\hline Elder (Ray aman'dreny) & 7 \\
\hline School administrator & 3 \\
\hline Teacher & 2 \\
\hline Religious leader & 1 \\
\hline Doctor & 1 \\
\hline Midwife & 2 \\
\hline Women's association representative & 2 \\
\hline Farmer's association representative & 1 \\
\hline Porter's association representative & 2 \\
\hline Local conservation agent (park staff) & 4 \\
\hline Hotel operator & 1 \\
\hline Local nonprofit representative & 1 \\
\hline
\end{tabular}

\begin{tabular}{ll}
\hline Regional & \\
\hline Regional forester & 1 \\
\hline Regional park manager & 1 \\
\hline Nonprofit (Malagasy organization) representative & 3 \\
\hline & 5 \\
\hline National & 2 \\
\hline National conservation manager & 1 \\
\hline Nonprofit (International organization) representative & 1 \\
\hline $\begin{array}{l}\text { Conservation donor (International organization } \\
\text { representative }\end{array}$ & \multicolumn{2}{l}{4} \\
\hline
\end{tabular}

a Occupational data for community key informants are grouped across the two study sites to protect the anonymity of participants.

b Elected leaders refer to leaders including the mayor (of an incorporated village) and the president of the local municipality (sefo ny fokontany), which are elected leaders in unincorporated rural areas. tive and stylistic nuances of the translator can affect translation. Using NVivo 8 software, transcripts were coded line-by-line and organized into major themes.

\section{RESULTS}

Socio-demographic data on key informants are described in Table 2. Ambodivoahangy had a greater population (over 1,100 residents in 145 households) than Antanandava where roughly 175 households contain a population of about 567 residents. Most of the informants in each study site were male, although a few more female leaders were interviewed in Ambodivoahangy than in Antanandava. Antanandava informants were older (mean age $=57$ ) than those in Ambodivoahangy (mean age =49) and had lived in their community somewhat longer (50 versus 43 years). Most residents in Antanandava were of the Sihanaka tribe and Betsimisaraka in Ambodivoahangy. On average, informants in Antanandava (38\%) were more likely to have either worked for the national park service or been directly employed by NGOs working on conservation projects with ZNP than those informants in Ambodivoahangy (29\%).

COMMUNITY PERSPECTIVES ON SOCIAL AND ECOLOGICAL

WELL-BEING I - THE SOCIAL IMPACTS OF GROWING FOOD INSECURITY. An interactional approach to understanding social well-being emphasizes community context and the interconnectedness of social and ecological influences. For example, in describing their communities, informants focused on the relationships with the landscape and forest (their ecological well-being) that supported their social well-being. Many informants emphasized subsistence farming when describing their communities: "Farming... and breeding. Concerning farming... first and foremost is rice...then food crops" (community elder). While many residents cultivate cash crops to supplement household income, they mainly depend on rice farming for their livelihood: "As far as food is concerned, some grow cassava, sweet potatoes, bananas, and so forth. But those are merely complementary foods. The main thing is rice - our staple food is rice. Some sell rice. If we suppose that 100 or 200 inhabitants live in this village, only three or four of them would sell part of their rice [stock]. Coffee and cloves are not real sources of income. The prices are too low. So low that people are disheartened. Concerning coffee, for example, people harvest just what they need for their own consumption. There's no surplus to sell. As for vanilla, as the prices dropped so low, people can no longer afford to take care of [their] crop. That is to say, people are not willing to invest themselves in such [a] crop that requires weeding, artificial/hand pollination, etc.)" (porter).

Regional and national informants also focused on subsistence farming when describing ZNP communities, reinforcing the notion that rice is life for many Malagasy people: "Farming is the true basis of their livelihood...rice-farming. In fact, their rice-crops constitute their whole means of livelihood. suppose they get their rice, that rice, in turn will be sold, so that they can buy clothing items, or house-building materials" (regional park manager).

Disruption to residents' ecological well-being (access to natural resources) subsequently affected their survival, security, and esteem (social well-being indicators). A major concern among informants in both communities, although a more salient issue in Ambodivoahangy, revolved around shortages of land for the practice of tavy (swidden agriculture). Tavy constitutes 
TABLE 2. Sociodemographic characteristics of setting and informants

\begin{tabular}{lcc}
\hline Description & $\begin{array}{c}\text { Antanandava } \\
(\mathrm{N}=16)\end{array}$ & $\begin{array}{c}\text { Ambodivoangy } \\
(\mathrm{N}=17)\end{array}$ \\
\hline Population & 567 & 1112 \\
\hline Total number of households & 175 & 145 \\
\hline Gender (\% male interviewed) & $88 \%$ & $82 \%$ \\
\hline Age & 57 & 49 \\
\hline Length of residence & 50 & 43 \\
\hline Tribal origin & Sihanaka & Betsimisaraka \\
\hline Park involvement & $38 \%$ & $29 \%$ \\
\hline
\end{tabular}

the primary method for practicing agriculture in this area and provides a means for insuring cultural heritage and connections to the ancestors (fomban-drazana) (Horning 2003). The consequence of land shortage is decreased yields from remaining available arable land (Antanandava, $\mathrm{n}=10$; Ambodivoahangy, $\mathrm{n}=15$ ). A community elder described these changes: "So, our former life and present life are now a long way apart, because in the past we had rice in plenty; but the people have grown in number and the lands haven't increased." In Ambodivoahangy, in particular, residents described how the amending of park boundaries and taking large tracts of savoka (degraded forest land used primarily for shifting cultivation) negatively impacted their livelihood: "The impact is that the savoka that were previously cleared by the people have been appended to the protected area. There aren't enough farm lands left" (women's group representative). Ambodivoahangy residents indicated "life is plagued by an unprecedented crisis, financially [and] food-wise." More importantly, what arable land was available to residents had continually decreased in fertility causing food crop yields to plummet. A community association representative described this crisis as leading to a sense of desperation among residents: "The soil no longer yields anything much, what the soil yields does not sell, and the little you reap, you derive nothing from it...no wonder poverty is rampant!"

A major concern among residents in both communities was how land shortages had brought about changes to their community in the form of theft, land disputes, and an overall decrease in life satisfaction and security. A community elder in Ambodivoahangy describes these changes: "There are changes in community life, due to food shortages. These are causing minor disputes, like land disputes...and also there is an increase in theft. This state of things started in 2001, approximately... that's when [it] really started proliferating... but [fortunately], they didn't happen every day, but every year. Food crops are what the thieves steal. The cause of land disputes is the growth of population, yet lands have been annexed into the Forest Reserve, and access to the Forest Reserve is prohibited. So the lands that used to ensure [our] livelihood have been taken. In community life...because of those minor disagreements... hate and distrust break out. In the past, however, people trusted one another."

Again, residents in both Antanandava $(n=5)$ and Ambodivoahangy $(n=14)$ noted their communities "had changed for the worse due to life's hardships," but this transformation had a far greater negative impact on Ambodivoahangy than in Antanandava. Undergirding this change was a sense of people not caring for one another like they had before; residents attributed this to "relationships becoming loose due to this excessive life adversity." An elder in Ambodivoahangy noted how such hardships had "shaken" their community: "The reason the people are not joyful is that poverty causes paralysis... And because of that they get, kind of...frustrated. They become annoyed because of that. Let's say... they grow crops. The income they derive from the little crops they get is far from enough and satisfactory. It also happens that the little they produce may get stolen. Whatever it is, anything they have may get stolen, land, produce, or raised animals alike. Peaceful living is kind of shaky here, at the moment."

Residents in Ambodivoahangy identified this change as occurring around the time of integrated conservation and development projects (ICDPS) involvement in ZNP in the 1990s. They linked the disruptions to community life and theft as resulting from lost access to land and decreased food security. A male resident noted: "Society was good before. But after 1990 through today, it was in trouble. The reason of this trouble is that according to a Malagasy proverb that "If the body is hungry, the soul is wandering." This means that hunger was reached deeply everyone; it appeared in 1990 until today - our community is in trouble. There is no rice, so he/she is forced to steal. The things that he/she could steal are rice, sweet potato, cassava... The anger had hit us hard in 2000 and still hit us until today because of land shortage, we don't have paddy rice fields here to use. As a result, robbery appeared."

Dissent by Ambodivoahangy residents regarding land loss and opposition to the gazetting of land during the establishment of ICDPS in the 1990s was also documented in past research on ZNP (Rabesahala 1995).

COMMUNITY PERSPECTIVES ON SOCIAL AND ECOLOGICAL

WELL-BEING II - THE DEPENDENCE OF LOCAL LIVELIHOOD OVER FOREST RESOURCES: ZNP residents' livelihood is solely based on the forest and the natural resources within it notably the land (used for subsistence farming) and forest products; these represent the ecological well-being of ZNP communities. Forest resources, both timber and non-timber forest products (NTFPS) provided daily benefit to residents in both communities. Fuelwood was the main form of cooking energy for many residents in both communities. Few people used charcoal since residents complained it was more costly than harvesting dead or green wood from community forests. Residents in both communities identified the daily importance of certain medicinal plants for curing "minor illnesses." A community elder described the use of volontsora (Eremolaena humblotiana), a herbaceous shrub found in the area: "There are some leaves we boil to make herb tea used as medicine, like when you have a stomachache, in the form of colic or diarrhea." Harvesting timber for building construction and furniture was also a primary forest resource for residents in both places. Residents in Antanandava noted most building materials and furniture was made from eucalyptus species found in the nearby community forest. They noted furniture and homes were previously constructed from hardwood species including voamboana (rosewood, Dalbergia baronii), but today limited access to the forest caused changes in hardwood availability and use.

For residents in Ambodivoahangy, the forest provided for all major sustenance and daily needs including hardwood species for home construction, food, and materials for decorative mats. While residents in Antanandava used forest resources daily, their primary needs were not as centered on the forest as in 
Ambodivoahangy. A teacher in Ambodivoahangy described how the change in access impacted their lives: "The drawbacks occur when it introduces problems because the old source of livelihood has been shut off by the government, so people cannot get in there anymore." More importantly, wild plants were a major source of food for Ambodivoahangy residents especially those collected on fallow land: "We pick things we use as laoka [all food that is served with rice], like the hearts of palm trees. Fishing, of course...like fishing with nets, fishing for crabs, [hunting] birds" (community elder). A regional NGO representative pointed out the differences in forest dependency between the two communities: "Ambodivoahangy inhabitants are those who really depend on the forests, because they are really close to the forest. The wood for house-building, for firewood, for tavy and so forth... all of that comes from the forests. They have ricepaddies out there, yet they practice tavy. As for Antanandava, they don't live off the forest all that much, because they are far away from the forests."

Additionally, the impact of lost access to land and forest resources within park boundaries was a major concern for Ambodivoahangy residents. Unlike Antanandava, many of the forest resources Ambodivoahangy residents required for their daily life could not be found in the community forest. A traditional leader in Ambodivoahangy outlined this dilemma: "All things that we could eat are inside the reserve, so we can't take them anymore. So we go to the community forest, but we can't find those things we could eat inside the community forest." During the rice shortage period, many Ambodivoahangy residents rely on cassava, oviala (a type of indigenous sweet potato) and various greens (e.g., ravimbomanga, sweet potato leaves and ravintoto, cassava leaves) to supplement their subsistence needs. Searching for laboring jobs is not a viable option for residents in Ambodivoahangy, as many families cannot afford to pay day laborers. A women's group representative described this dilemma: "You decide to take a laboring job, your wages will be about 600 Ariary per day. Yet, one cup of rice nearly costs 300-350 Ariary already. No wonder we are poor." As for timber resources in Ambodivoahangy, many residents reported they acquire fuelwood and timber for home construction from the community forest, yet note it no longer meets their resource needs and has degraded over time: "The nearby forest is now dramatically thinned out. The one in the distance is still replete with trees, but it's prohibited. The [community] forest no longer has enough timber for the taking, because of the number of people who help themselves there, though many trees still grow" (woman, Ambodivoahangy).

POLITICS OF CONSERVATION - RELATIONSHIPS

BETWEEN ZNP COMMUNITIES AND PARK MANAGERS.

The establishment of ZNP by government decree not only impacted residents' livelihoods and well-being by imposing external control over local resource use and access, but also changed how residents viewed the park itself. ZNP residents recognized the importance of protecting the forest, but, overall, failed to see how the park provided any direct benefits to them. Many residents recognized the intrinsic natural resource benefit of ZNP, indicating the forest within the park boundaries brought them "rain to feed our fields and water in our rivers," but did not see how it benefitted them in their daily lives beyond these ecological benefits. They also felt the park didn't belong to them anymore, displaying a sense of dispossession (Kepe 2004) and deprivation (Blaustein 2007) due to creation of the park: "It's now government property." One community elder said: "As I've just said, Zahamena has always existed... but there was also the part that belonged to us... which ensured our livelihood. But now, it's gone."

Along with a sense of disconnect from the park, residents believed managers only cared about protecting the park at all costs and did not care about the welfare of local communities. One farmers' association representative said: "They will protect the lemurs, that's what they do, but who will protect us?!" Also, many informants describe how local conservation agents and managers distanced themselves from local residents. A community group representative stated: "They aren't even capable of getting together and speaking with the community. They enforce and tighten up their protection, but they don't suggest any solutions to us villagers."

At the same time, residents recognized past support ZNP managers had given through ICDPS like building schools, dams, and providing other social infrastructure. However, residents believed such support dwindled over the years and now was nonexistent. Moreover, residents reported that livelihood alternatives through ICDPS like tourism, did not improve their life situation. A women's group representative voiced her concern: "The changes I've seen they have brought are lies. I will not hide my thoughts - they have brought lies. I call it lies because the very moment the forest was closed they set up a series of projects, [saying] that the villagers should be provided with alternative solutions now that their source of livelihood was banned for protection. So they provided funds, they created different organizations... but it's now left unfinished. It's been a huge disappointment for us!"

Park managers believed ZNP communities did not see the utilitarian value of the park as a place that should be protected for the sake of conserving biodiversity and promoting tourism: "It's a good thing that the management has been put in place, because that's exactly what we aimed at, which is, to perpetuate [its existence], knowing that the protection of Zahamena National Park ensures many things around here. For example, it ensures the waters that flow into Alaotra, that [fills up] the dam of Andekaleka. Ecologically, upon the very existence [of Zahamena] depends the life of this region of Alaotra-Mangoro and Analanjirofo. Additionally, it is a recreational place for the tourists to visit" (local park staff).

Managers said infractions and degradation occurred in the reserve because people didn't see "the true value" of the park. Regional managers were especially adamant that ZNP residents "think the park belongs to them still and that is why they keep destroying it. They don't value it like we do." ZNP regional and national informants claimed there have been no changes in access to the park and forest reserve, stating it was always a protected area. They believed nothing had changed, except perhaps the official status change of integrated nature reserve to a national park. One regional representative said, "Zahamena is not 'closed off.' The people think it is closed off because of the presence of managers. They say it's shut off, but actually it has always been shut off." While there are no physical barriers around ZNP, the park managers are referring to the notion of the governmental policy declaring ZNP inaccessible to all residents. Their expression (mihidy) literally translates to 'closed.' 


\section{DISCUSSION AND IMPLICATIONS}

This article explored how perceptions of social well-being were influenced by ecological, social, and political processes within a locality. These processes were based on the interrelationships between the social and ecological processes and notably how changes in the landscape induced changes in the community. Reflecting the tripartite interdependency of individual, community, and ecological well-being, disruptions in access to land and forest resources brought about distinct changes in residents' livelihoods, community (behavior, social norms, etc.), and individual well-being. As hardships emerged, especially in the form of the described food crisis, informants expressed a sense of discontent and loss of caring for one another among community members, which was not the case previously. A clear deterioration of the social fabric of both communities was described, yet these changes had a far greater negative impact on the residents in Ambodivoahangy than those in Antanandava. Informants believed crime, in the form of stealing food crops, existed prior to the park, but incidents increased over time especially as crop yields of both rice and cash crops continued to plummet. Although residents in Ambodivoahangy were more dependent on forest resources in their daily lives than those residents in Antanandava, informants in Antanandava still described a sense of disruption to community life. Toillier et al. (2011) noted similar negative impacts including an increase in individualism (lack of caring for others) and impoverishment resulting from community-based forest management in communities near Ranomafana National Park. Similar findings were noted with regard to how abrupt changes in resource access and availability created strains, albeit more extensively, on social life for the Ik people of Uganda (Turnbull 1972).

Underlying these changes in social well-being for ZNP communities were the political processes due to the creation of the park, or the 'conservation control' that affected changes in the landscape. Residents in both communities described how certain forest resources they once harvested were now off-limits since they were within park boundaries. For Ambodivoahangy residents, this change caused greater disruptions to their well-being due to the Betsimisaraka tradition of practicing tavy. While some residents in Ambodivoahangy practice paddy rice farming, the majority relied on tavy for their rice cultivation. Unlike residents in Antanandava, they did not have access to vast areas of flat land to practice rice-paddy farming; flat surfaces are rare and found predominantly in narrow strips along river and stream edges. The terrain within the enclave of ZNP surrounding Ambodivoahangy is very hilly as elevation varies between 550 and 1,300 meters with slopes at times greater than 30 percent (MNP 2009, Rabesahala et al. 1995). Tavy was the main form of subsistence farming available to residents, therefore access to tavy land was how they secured their livelihoods. The establishment of the park and continued amending of conservation policies affecting access to residents' savoka land removed much arable land from production; at the same time, it reduced residents' potential to provide for their daily needs. While no official record exists of how much land was acquired from the residents of Ambodivoahangy, two informants in Ambodivoahangy in particular indicated their families had lost between 500 to 1,000 hectares in total over the years since the park was established in 1927. A rigorous measurement of actual changes in park and farmed land (tavy) boundaries should now be conducted in order to assess more precisely the park's impact on people's livelihood.

Reinforcing the notion of control through conservation (Robbins 2004), the establishment of ZNP by state and/or government entities in the name of conservation changed local social and cultural habits, thereby disrupting local livelihoods of its residents. Informants in both communities acknowledged this political and social change, as they believed the park and its resources were no longer theirs and belonged to the state. This change in mentality from thinking the park was a source for collective resource use to now a restricted protected area was reflected in residents' perceptions about the park. They continued to value the park for its intrinsic ecological benefits (rain for their fields and water in their rivers), but indicated it did not provide any direct benefits to them.

There was a divergence between community and park service staff (regional and national) views about park values and benefits. Park service staff felt residents did not value the park nor recognize its benefits, which they believed was illustrated by residents' local tavy practices. However, similar to other research on the community values of protected areas (Keller 2008) residents did value the park, but felt the benefits offered through ICDPs did not improve their overall life situation or livelihood. According to informants, the expectation of tourism revenues and the creation of development projects fell through and many were left unfinished. However, the effectiveness of ICDPS in providing community benefits has been contested (Fortwangler 2003). In fact, research elsewhere on the social impact of conservation in Madagascar, reported that ecotourism programs inviting wealthy westerners to protected areas inflates local market prices of staple foods, medicine, and cost of living (Hanson 1997).

This study illustrated how changes in ecological, social, cultural, and political processes in place influenced social wellbeing. Findings were not representative of all ZNP communities nor identified the causal factors related to conservation, forest dependency, and social well-being. To determine if all park residents share similar perspectives, future research would focus on obtaining a larger and more representative sample from numerous communities within the park periphery. With a larger sampling frame, it is expected more significant linkages and causal explanations would emerge. Nonetheless, study results reflect similar concerns and issues facing many other populations living adjacent to protected areas and national parks, especially those in Madagascar. The case of ZNP further supports the body of literature on the social impacts of conservation by underscoring how changes in the landscape could disrupt community well-being. Rather than focusing on a specific outcome, for example conservation initiatives examining protected area impact, policymakers and managers could apply the integrated framework used here to evaluate well-being of locally affected communities. Applying such a framework in current protected area management policies, enables managers to merge conservation policies and outcomes with community livelihood needs. Such a framework explicitly considers processes at the community level, and how local and extra-local political factors affect social well-being. Using such an approach, a more holistic picture of impacts emerges, reflecting the multiple facets and interactions of subsistence strategies, social relations, power influences, 
locally held traditions, and community beliefs about conservation. Essentially, this framework ensures the most valuable resource in national parks and reserves does not become a forgotten resource - like the residents of ZNP. This research confirms humans are just as necessary a resource to promote conservation and protected area management in Madagascar and across the globe. In order to create collaborations and partnerships with the people living near protected areas, their needs and concerns must be addressed.

\section{ACKNOWLEDGMENTS}

This research was supported by the Office of International Programs, College of Agricultural Sciences and the Alliance for Education, Science, Engineering and Development in Africa (AESEDA), University Office for Global Programs, The Pennsylvania State University, University Park, PA USA. I thank the people of Antanandava and Ambodivoahangy for their exceptional hospitality, patience, and willingness to accept me into their communities and homes. Thanks to Mamitiana Rakotozafy for assistance in facilitating my fieldwork. Special thanks to Farrah Malala, Bernard Randrianarisoa, Isidore Ralaingita, Pactole Alison, Remi Randremizara, and especially Benoit Rakotovao. Also, I thank Professors A. E. Luloff, Jason Gordon, Brad Woods, Jacques Pollini, Barry Ferguson, and two anonymous reviewers for their very helpful comments and suggestions to improve this article, any shortcomings, however, are mine alone.

\section{REFERENCES}

Andriamampianina, J. 1984. Nature reserves and nature conservation in Madagascar. In: Key Environments: Madagascar. A. Jolly, P. Oberlé and R. Albignac (eds.), pp 219-227. Pergamon Press, Oxford.

Battistini, R. and Richard-Vindard. G. 1972. Biogeography and Ecology in Madagascar. Junk Publishers, The Hague.

Blaustein, R. J. 2007. Protected areas and equity concerns. Bioscience 57 3: 216-221. (doi:10.1641/B570303)

Brechin, S. R., Wilshusen, P. R., Fortwangler, C. L. and West, P. C. 2002. Beyond the square wheel: Toward a more comprehensive understanding of biodiversity conservation as social and political process. Society and Natural Resources 15, 1: 41-64. (doi:10.1080/089419202 317174011)

Burdge, R. J. 2004. The Concepts, Process and Methods of Social Impact Assessment. Social Ecology Press, Middleton.

Conservation International (CI). 1999. La Monographie de Zahamena. Antananarivo, Madagascar. Conservation International Madagascar. $154 \mathrm{pp}$.

Creswell, J. W. 2007. Qualitative Inquiry and Research Design. Sage Publications, Thousand Oaks.

Diener, E., Suh, E., Lucas, R. E. and Smith, H. L. 1999. Subjective well-being: Three decades of progress. Psychological Bulletin 125, 2: 276-302. (doi:10.1037/0033-2909.125.2.276)

Djagba, J. 2012. Zahamena National Park (ZNP) and location of study sites. [Digital data]. Digital composite map of a georeferenced paper map, "Zahamena National Park" in Madagascar National Parks [2009] for use in a GIS. Produced by J. Djagba, Africa Rice Center (AfricaRice), GIS Unit, 2012.

Dutcher, D. D., Finley, J. C., Luloff, A. E. and Johnson, J. 2004. Landowner perceptions of protecting and establishing riparian forests: A qualitative analysis. Society and Natural Resources 17, 4: 319-332. (doi:10.1080/08941920490278773)

Ferraro, P. 2002. The local costs of establishing protected areas in lowincome nations: Ranomafana National Park, Madagascar. Ecological Economics 43, 2-3: 261-275. (doi:10.1016/S0921-8009(02)00219-7)
Fortwangler, C. L. 2003. The winding road: Incorporating social justice and human rights into protected area policies. In: Contested Nature: Promoting International Biodiversity with Social Justice in the Twentyfirst Century. S. R. Brechin, P. R. Wilhusen, C. L. Fortwangler and P. C. West (eds.), pp 25-39. State University of New York Press, Albany.

Gezon, L. L. 1997. Political ecology and conflict in Ankarana, Madagascar. Ethnology 36, 2: 85-100.

Gezon, L. L. 2006. Global Visions, Local Landscapes: A Political Ecology of Conservation, Conflict, and Control in Northern Madagascar. AltaMira Press, Lanham.

Ghimire, K. B. and Pimbert, M. P. 1997. Social change and conservation: An overview of issues and concepts. In: Social Change and Conservation. K. B. Ghimire and M. P. Pimbert (eds.), pp 1-45. Earthscan Publications, London.

Guillaumet, J.-L. The vegetation: An extraordinary diversity. In: Key Environments: Madagascar, A. Jolly, P. Oberlé and R. Albignac (eds.), pp 27-54. Pergamon Press, Oxford.

Hanson, P. W. 1997. The Politics of Need Interpretation in Madagascar's Ranomafana National Park. Unpubl. Ph.D. thesis, University of Pennsylvania, Philadelphia.

Harper, J. 2002. Endangered Species: Health, Illness and Death among Madagascar's People of the Forest. Carolina Academic Press, Durham.

Horning, N. R. 2003. The cost of ignoring rules: How Madagascar's biodiversity and rural livelihoods have suffered from institutional shortcomings. Paper presented at The International Conference on Rural Livelihoods, Forests and Biodiversity 19-23 May 2003, Bonn, Germany.

Keller, E. 2008. The banana plant and the moon: Conservation and the Malagasy ethos of life in Masoala, Madagascar. American Ethnologist 35, 4: 650-664. (doi:10.1111/j.1548-1425.2008.00103.x)

Kepe, T. 2004. Land restitution and biodiversity conservation in South Africa: The case of Mkambati, Eastern Cape Province. Canadian Journal of African Studies / Revue Canadienne des Études Africaines 38, 3: 688-704.

Keyes, C. L. M. 1998. Social well-being. Social Psychological Quarterly 61, 2: 121-140.

Kull, C. A. 1996. The evolution of conservation efforts in Madagascar International Environmental Affairs 8, 1: 50-86.

Madagascar National Parks (MNP). 2009. Plan de Gestion de Conservation du Parc National de Zahamena. Antananarivo, Madagascar: Madagascar National Parks. 69 pp.

Marcus, R. R. 2001. Seeing the forest for the trees: Integrated conservation and development projects and local perceptions of conservation in Madagascar. Human Ecology 29, 4: 381-397. (doi:10.1023/A:1013189720278)

Mittermeier, R. A., Hawkins, F., Rajaobelina, S. and Langrand, O. 2005. Wilderness conservation in a biodiversity hotspot. International Journal of Wilderness 11, 3: 42-45

Parcs Nationaux Madagascar (PNM) \& Conservation International (Cl) Madagascar. 2001. Plan d'Aménagement et de Gestion du Parc National de Zahamena, 2001-2005. Antananarivo, Madagascar: Conservation International (Cl) Madagascar. 144 pp.

Peters, J. 1999. Understanding conflicts between people and parks at Ranomafana, Madagascar. Agriculture and Human Values 16, 1 : 65-74. (doi:10.1023/A:1007572011454)

Rabesahala, N., Gauthier, M. and Rakotoarisoa, B. 1995. Conception and Development of a Contract Agreement for the Sustainable Use of Natural Resources (Zahamena, Madagascar). Prepared for ANGAP (Association Nationale pour la Gestion des Aires Protégées) and USAID/Madagascar, SAVEM Project. 90 pp.

Rabesahala, N., Rakotoarisoa, H., Ramambasoa, H., Rasamison, F. \& Rasolofonjatovo, J. E.. 1994. Données recueillies sur la gouvernance locale à Madagascar : communautés de Zahamena. Prepared for USAID/Madagascar, KEPEM Project. Decentralization: Finance and Management Project. Contract No DHR-5446-Z-00-7033-00. Burlington, VT: Associates in Rural Development, Inc. 123 pp.

Robbins, P. 2004. Conservation and control. In: Political Ecology: A Critical Introduction. P. Robbins (ed.), pp 147-171. Blackwell Publishing, Oxford. 
Scott, J. C. 1990. Dominance and the Art of Resistance: Hidden Transcripts. Yale University Press, New Haven.

Simsik, M. 2002. The political ecology of biodiversity conservation on the Malagasy Highlands. Geojournal 58, 4: 233-242. (doi:10.1023/ B:GEJO.0000017954.58269.69)

Shyamsundar, P. and Kramer, R. 1997. Biodiversity conservation - at what cost? A study of households in the vicinity of Madagascar's Mantadia National Park. Ambio 26, 3: 180-184.

Sodikoff, G. M. 2007. An exceptional strike: A micro-history of 'people versus park' in Madagascar. Journal of Political Ecology 14: 10-33.

Swanson, L. 1992. Rural social Infrastructure. In: Foundations of Rural Development Policy. J. N. Reid (ed). Westview Press, Boulder.

Thomas, W. I. and Thomas, D. S. 1928. The child in America: Behavior problems and programs. Knopf, New York.

Toillier, A., Serpantié, G., Hervé, D. and Lardon, S. 2011. Livelihood strategies and land use changes in response to conservation: Pitfalls of community-based forest management in Madagascar. Journal of Sustainable Forestry 30, 1-2: 20-56. (doi:10.1080/10549811003742357)

Turnbull, C. M. 1972. The Mountain People. Simon and Schuster, New York.

Watts, M. J. 2000. Political ecology. In: A Companion to Economic Geography E. Sheppard, T. Barnes and A. Malden (eds.), pp 257-274. Blackwell Publishing, London.

Weiss, R. S. 1994. Learning from Strangers: The Art and Method of Qualitative Interview Studies. The Free Press, New York.

Wilkinson, K. P. 1979. Social well-being and community. Journal of the Community Development Society 10, 1: 5-16. (doi:10.1080/15575330. 1979.9987075)

Wilkinson, K. P. 1991. The Community in Rural America. Greenwood Press, Westport.

Zerner, C. 2000. Toward a broader vision of justice and nature conservation. In: People, Plants, and Justice: The Politics of Nature Conservation, C. Zerner (ed.), pp 3-20. Columbia University Press, New York.

\section{SUPPLEMENTARY MATERIAL}

AVAILABLE ONLINE ONLY.

TABLE S1. Key informant interview guide. 